\title{
Economic Empowerment of Local Community around Cipendok Tourist Attraction in Banyumas Regency
}

\author{
By: \\ Abdul Aziz Ahmad ${ }^{1)}$, Emmy Saraswati ${ }^{2)}$, Dijan Rahajuni ${ }^{3)}$ \\ ${ }^{1,2,3)}$ Faculty of Economics and Business, Universitas Jenderal Soedirman \\ ${ }^{1)}$ Email: abdulazizahmad@yahoo.com
}

\begin{abstract}
Curug Cipendok is one of natural tourism destinations in Banyumas Regency. As an icon of Banyumas tourism destination, the development of Curug Cipendok has the potentials to increase economic benefit to local communities. Related to the tourism development program based on ecological conservation and effort to provide economic contribution to local community in the surrounding area, this research made an attempt to describe how the tourism object would generate benefit to the local community. This research found out that local community considered that the development project of Curug Cipendok tourist attraction has not provided direct impact to the economic benefit. The community has received indirect impact such as street maintenance and other transportation infrastructure. Related to strategies to develop the economy of local community at Cipendok area the policies to be implemented are; 1 ) synchronizing interests of local government and PT Perhutani to optimize the utilization of natural forest to local community in ecological conservation scheme; 2 ) leading to active collaboration among local government and PT Perhutani involving university and private sector to establish strategies, and implementing the strategies to support in creating creative industrial products and increase farming value added to local community; and 3) developing regulation focusing on environmental support capability to control any negative impacts of tourism development, including protection to local heritage.
\end{abstract}

Keywords: Curug Cipendok, Local Community, Ecological Conservation, Local Heritage.

\begin{abstract}
ABSTRAK
Curug Cipendok adalah salah satu tujuan wisata alam di Kabupaten Banyumas. Sebagai ikon tujuan wisata Banyumas, pengembangan Curug Cipendok memiliki potensi untuk meningkatkan manfaat ekonomi bagi masyarakat setempat. Terkait dengan program pengembangan pariwisata yang didasarkan pada konservasi ekologi dan upaya memberikan kontribusi ekonomi kepada masyarakat setempat di daerah sekitarnya, penelitian ini berusaha untuk menggambarkan bagaimana objek wisata akan menghasilkan manfaat bagi masyarakat setempat. Penelitian ini menemukan bahwa masyarakat setempat menganggap bahwa proyek pengembangan objek wisata Curug Cipendok belum memberikan dampak langsung terhadap manfaat ekonomi. Masyarakat telah menerima dampak tidak langsung seperti pemeliharaan jalan dan infrastruktur transportasi lainnya. Terkait strategi untuk mengembangkan ekonomi masyarakat lokal di kawasan Cipendok maka kebijakan yang akan diterapkan adalah; 1) sinkronisasi kepentingan pemerintah daerah dan PT Perhutani untuk mengoptimalkan pemanfaatan hutan alam kepada masyarakat lokal dalam skema konservasi ekologis; 2) mengarah pada kolaborasi aktif antara pemerintah daerah dan PT Perhutani yang melibatkan universitas dan sektor swasta untuk menetapkan strategi, dan menerapkan strategi untuk mendukung dalam menciptakan produk industri kreatif dan meningkatkan nilai tambah pertanian bagi masyarakat setempat; dan 3) mengembangkan regulasi yang
\end{abstract}


berfokus pada kemampuan dukungan lingkungan untuk mengendalikan setiap dampak

negatif dari pengembangan pariwisata, termasuk perlindungan terhadap warisan lokal.

Kata Kunci: Curug Cipendok, Masyarakat Lokal, Konservasi Ekologi, Warisan Lokal.

\section{INTRODUCTION}

Tourism according to the applicable law is all tourism-related and multidimensional and multidisciplinary activities that arise as a manifestation of the needs of every person and country, as well as the interaction among tourists, local community, fellow tourists, government, local government, and employers (Law No. 10/2009 on Tourism). The scope of tourism is broad. There are five types of activities within the scope of tourism, including: maritime tourism (beach and sun tourism), rural and agro tourism, natural tourism, cultural tourism, and business travel. In its position as a driver of the economy, tourism serves as ecotourism, which is an effort to explore the economic benefits of tourism activities. The International Ecotourism Society (TIES, 2006) mentions that ecotourism can be interpreted as professional, well-trained travel activities and contains an element of education, as an economic business sector, which considers the cultural heritage, participation and welfare of local people as well as efforts to conserve natural resources and the environment (Agustyaningrum et al., 2016).

As one component of regional development, tourism development is a coordinated activity and effort to attract tourists, provides necessary infrastructure, and serves the needs of tourists who come to visit. Tourism development is a development covering many broad aspects, both to the community and to the overall economy. The development of tourism in the region is directed to the improvement of the tourism sector to become a reliable sector capable of mobilizing regional economic activities, especially the local economy. The tourism sector is also an open sector for employment creation, increasing income of community and local revenue (Yusmiadi and Witjaksono, 2012).

Ecotourism pattern needs to carry out community-based activities, which is ecotourism development pattern that support and enable full employment by local communities in the planning, implementation, management of ecotourism business and all the benefits gained. Community-based ecotourism is an ecotourism that emphasizes the active role of the community. This is based on the fact that the community has knowledge about nature and culture that become the potential and selling value as a tourist attraction, so that the community involvement is absolute.

The key aspects of community-based ecotourism according to the Directorate General of Tourism Destination of the Department of Culture and Tourism (2009) are:

(1) The community establishes a committee or institution for the management of ecotourism activities in its area with support from government and community organization (the value of community participation and education).

(2) Local ownership principles (management and ownership by local community) are applied to ecotourism facilities and infrastructure in the ecotourism area (the value of community participation).

(3) Homestay is the main choice for accomodation facilities at tourist site (economic and educational value).

(4) The guides are local people (the value of community participation).

In nature-based tourism development, community participation is conducted in the form of community forest, social forestry, Management Regime (MR) system and reforestation. Local people around the natural attraction have the potential to participate in managing, supporting and ensuring the sustainability of the existing natural attractions (Primadany et al., 2013). In addition, economically, the people can also enjoy the benefits gained in the management of the natural resources (Demartoto, 2009).

Demartoto (2009) also states that the participation of local community in the management of natural tourist areas is able to drive socio-economic development and provide income sources for 
local community that does not threaten basic natural resources, provide holistical benefits to local community, such as improving morale, economy, and environmental objectives. Participatory approaches that can be carried out to local community around tourist area are through education, revenue sharing approach and participation in decision making as well as appropriate development schemes around the ecotourism area (Purwanti, 2015; Suryani, 2016).

The researches on the empowerment of tourism-based local economy have been widely conducted. Some of these researches are: 1) Sukmana (2010) concludes that the development pattern of flower tourist village in Batu City tourist area in Malang is a good concept model in community empowerment program based on potential and local value. The program is able to increase the attractiveness of the Tourism Destination Area (TDA) in supporting the development program of Batu City as a tourism city; 2) the research results of Wijayanti et al. (2008) conclude that the demand for recreation in the area of Mount Salak Endah Bogor regency is more affected by travel cost, distance, family income, education level factors, and information factor that the tourists know the existence of tourist attraction.

Related to the development of ecotourism area, one of the areas relying on nature-based tourism area is Banyumas Regency. The potential area to be developed is Cipendok tourism area, especially related to the development of Cipendok ecotourism area. Cipendok is the name of waterfall (curug) administratively located in Karang Tengah Village, Cilongok Sub-District, Banyumas Regency. Curug Cipendok is located on the slope of Mount Slamet. As the location where Curug Cipendok is located, the community of Karang Tengah Village claimed that they have not gained benefits from the existence of Cipendok tourism. This village tends to benefit more from the primary sector (agriculture) than from the service sector or processing industry (Ahmad and Emmy, 2016).

As a tourist icon in the region, the development of Curug Cipendok has the potential to increase people's income around the tourist attraction. Related to ecological-based tourism development and the need to contribute to the community around the tourist attraction, the effort should be made to explore the benefits of the development of Cipendok tourist attraction for the surrounding community.

\section{ANALYTICAL METHOD}

This research is a qualitative research relying on the findings from the data obtained in the field. Data are obtained from the observation result in the field through survey and interview with the community, including local tourism stakeholders and community around Cipendok tourist attraction. Qualitative data are then formed a matrix with SWOT-based methodology.

SWOT is the identity of various factors systematically to formulate service strategy. This analysis is based on logic to maximize opportunities and at the same time to reduce weaknesses and threats. S and $\mathrm{W}$ identify strengths and weaknesses of the region internally, in this case are related to the performance of investment management. $\mathrm{O}$ and $\mathrm{T}$ are the analysis of external factors in the form of opportunities and threats, including social, technological, economic, political, legal, environmental, demographic and competitor aspects. Thus, SWOT analysis (Strength, Weakness, Opportunity, and Threat) is based on the logic to maximize the strength of internal factors and opportunity of external factors, while simultaneously minimize internal weakness and reduce disturbance factor and potential external threat.

\section{RESULT AND DISCUSSION}

From the field observation, it is obtained the distribution of respondents by gender, education and job. According to gender, the majority of respondents are male by $66.7 \%$, the the remaining respondents are female by $33.3 \%$. According to education category, the majority of Cipendok people have relatively low education. Most of the respondents completed primary school (40.0\%), followed by the respondents who did not complete primary school (26.7\%). The respondents who completed secondary school are $20.0 \%$. While the respondents who completed high school are $13.3 \%$. The field survey conducted by the researcher did not obtain the respondents with higher education or 
university. However, there is a possibility of higher educated respondents. In terms of economy, the community of Cipendok is categorized to have low income. This can be identified from the condition of their house.

The majority of local communities as respondents or $53.3 \%$ state that Cipendok tourist attraction basically provides significant benefits for them. The benefits of Curug Cipendok tourist attraction do not directly affect the increase in income of local community. In contrast, $46.7 \%$ of respondents state that Cipendok tourist attraction does not significantly affect their income.

Although the positive impact of Cipendok tourist attraction is indirect, $50 \%$ of respondents state that local communities consider that the presence of Curug Cipendok is able to increase employment. Similarly, the presence of the tourist attraction also has an impact on the improvement of facilities and infrastructure. The existence of paved roads to the tourist site greatly contributes to the accessibility of the community in interacting one another. The additional factor of knowledge is the aspect that is most likely to have the greatest impact on the community. $73.3 \%$ of people consider that the development of Cipendok tourist attraction directly encourages people to learn through interaction with the visitors.

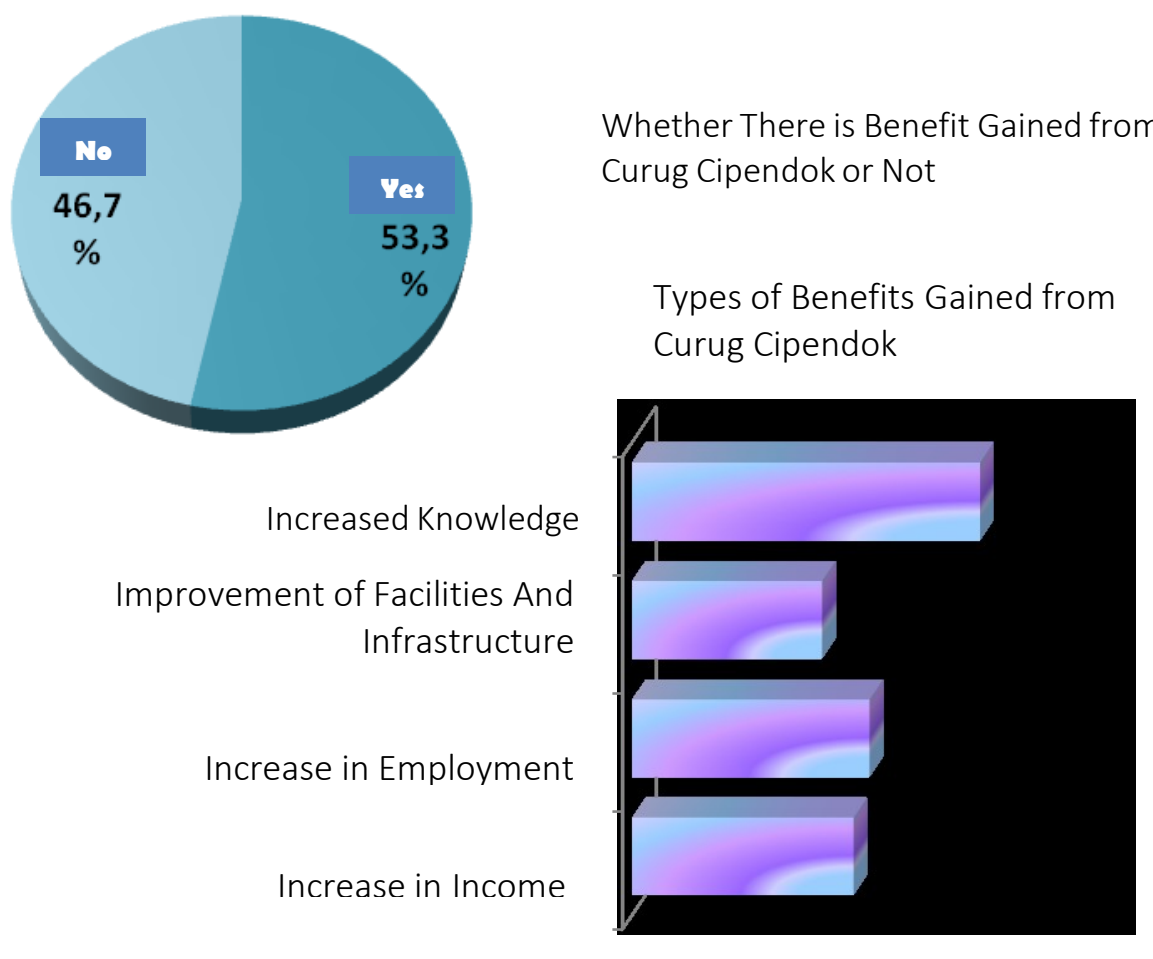

Figure 1. Local Community Preference on Curug Cipendok Benefits

With the benefits gained by local community, in general, local people tend to consider that Cipendok tourist attraction does not have a negative impact. $26.7 \%$ of local community consider that Cipendok tourist attraction has potential harm. The types of disturbance experienced by local community are the aspects of tourist behavior, increased pollution and the possibility of increasing waste. Waste is the most feared type of disturbance by the local community.

In terms of its development, the local community considers that there is a low rate of further development of Cipendok tourist attraction in the last few years. This is identified from the local community who tends to argue that the condition of Cipendok tourist attraction relatively does not have significant changes and tends to get worse. $54 \%$ of respondents consider that there is no significant development in Cipendok tourist attraction and $33 \%$ of respondents consider that this tourist attraction tends to get worse. Only $14 \%$ of respondents consider that there is significant development in Cipendok tourist attraction. 
The overview is described in the preference of local community on the condition of Cipendok tourist attraction. From the field survey, it can be obtained information that the category of transportation and road infrastructure is low in development. Only $6.7 \%$ of respondents consider that the effort to provide public transportation to tourist attraction is better. The majority of respondents consider that the effort for the development of transportation facility is relatively poor and very poor $(90.0 \%)$. This is similar to the condition of road infrastructure, where only $16.7 \%$ of respondents state that road construction is relatively adequate and good. In terms of tourist attraction condition, in general, $53.3 \%$ of respondents consider that the condition of tourist attraction relatively has no significant development and tends to get worse. This condition is also driven by the decreasing function of facilities and infrastructure within the tourist attraction. The respondents consider that the facilities and infrastructure in the tourist attraction are relatively poor (76.7\%).

The low effort to improve the tourist attraction is the cause of the decreasing function of facilities and infrastructure at the tourist attraction. $90 \%$ of the respondents consider that the effort to improve the tourist attraction is relatively low. In addition, it is considered that there is no significant development in effort to improve and organize the environment of tourist attraction. Although the local community considers that there is inadequate effort to improve the condition of Curug Cipendok tourist attraction, the community considers that the tourist attraction has a high potential if it is further developed. The local community expects that the improvement in facilities and infrastructure at the tourist attraction and the surrounding environment will have a positive contribution to their economy.

Therefore, the local community expects the expansion of tourism types to be able to attract more tourists and at the same time provides benefit of employment for the local community. the additional tourism types to be developed are primarily tourist village, fruit and vegetable garden, and forest park tourist attraction. The existence of tourist village will directly enhance the active role of local community in the development of tourist attraction in the region. Variety of local potentials will be developed if the government seeks to promote tourist village potentials. Similarly, the existence of fruit and vegetable garden is expected to encourage increased horticulture production in Banyumas and attracts the tourists. The concept of fruit and vegetable garden tourism has proved to have a positive impact on the local economy in several other regions. On the other hand, the effort of tourism expansion can be a forest park that will encourage the involvement of local people in Cipendok tourism activities as a provider of various servic es and products for tourists.

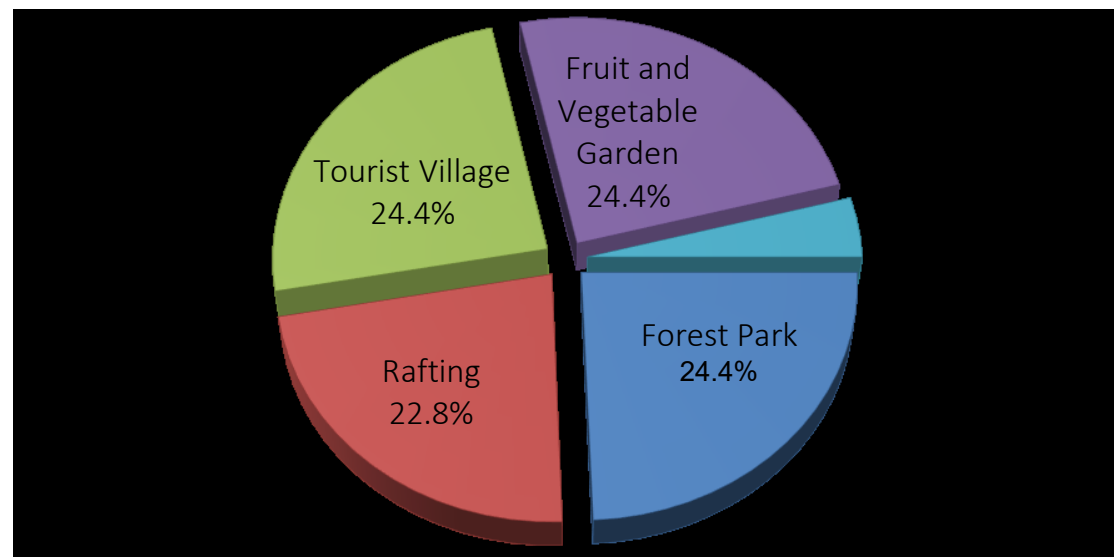

Figure 2. Possibility of Tourism Type Expansion by Local Community 


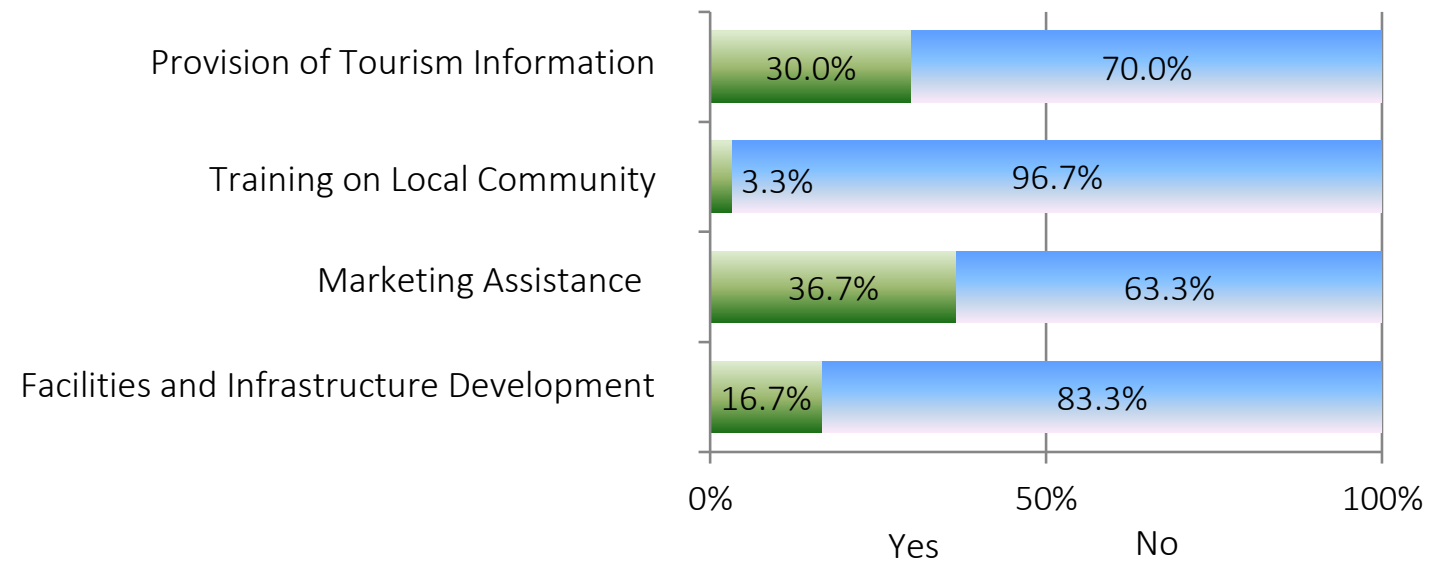

Figure 3. Several Forms of Government Role on Local Community Empowerment

In relation to some types of assistance for business development of local community, the respondents consider that the provision of such assistance is minimum. In terms of infrastructure development including business place and village market, only $16.7 \%$ of respondents claim to gain benefits. Similarly, according to the type of training in the surrounding population, only $3.3 \%$ of respondents claim to gain benefits. The better type of assistance is in the form of tourism socialization and product marketing assistance. Each of of these local community empowerment efforts is received by approximately $30.0 \%$ and $36.7 \%$ of the population.

The roles of government agencies, private sector and other parties in encouraging the local community's economy in Cipendok are needed. The survey result indicates that almost all local people want the assistance. Only $6.7 \%$ of respondents who consider the assistance is not needed.

From various types of business expected to encourage the increasing income of local community, the effort to empower the potential of forest products is the most desirable business. All respondents want this type of business. Community involvement around the forest in the use of state forest is common. By looking at local wisdom and forest conservation effort, community involvement to use state forests requires intensive coordination between government agencies, private sector and PT Perhutani.

Another type of business is the assistance in the form of community empowerment to raise cattle and chickens. $96.7 \%$ of respondents agree on this type of assistance. While goat farm is less desirable than cattle and chicken farms.

Curently, the determination of the location of Cipendok as a cattle farm has been sought. However, the community involvement in the farm is low. Local community expect their active involvement in the business. The involvement can be in the form of plasma-core cooperation, livestock raising assistance to the community in the form of desa binaan (village under development) and the establishment community cooperation. The absence of respondents' rejection on institutional effort to empower local community suggests a positive expectation of local community in an effort to improve their economic welfare. 


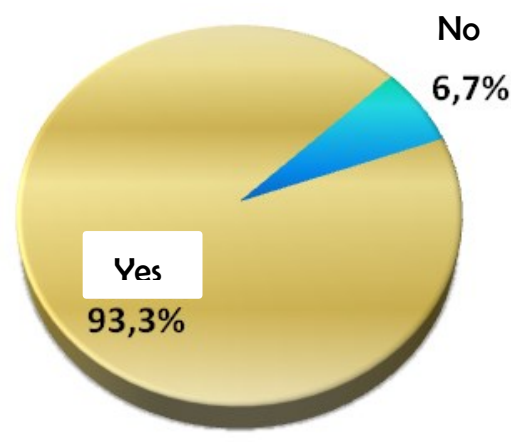

The Need for Business Improvement from the Community around Curug Cipendok

Empowerment of Forest Product Potentials

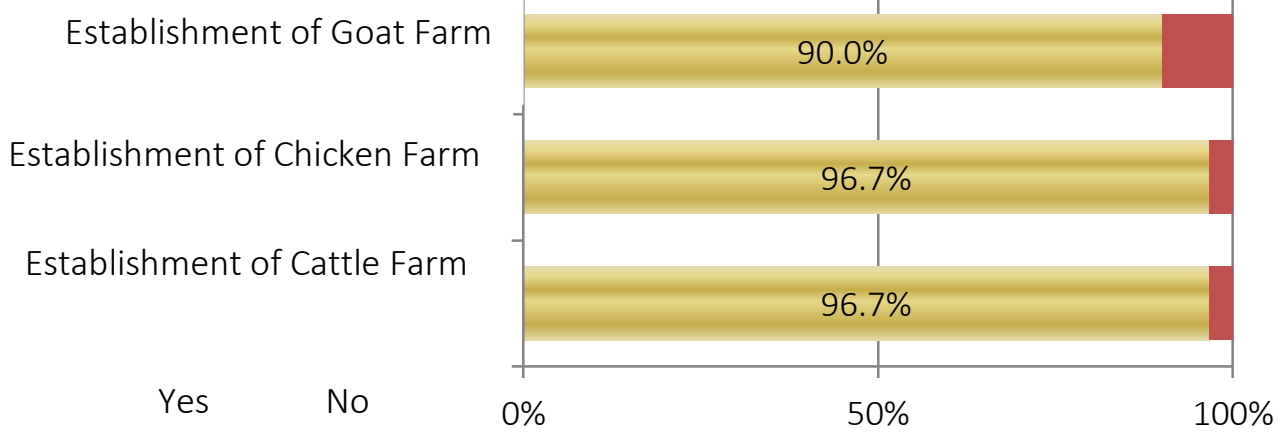

Figure 4. The Need and Business Type to Increase Local Community Income

Initially, the existence of Curug Cipendok tourist attraction is expected to be able to increase the income of surrounding community because the community expectation is that there will be a lot of labor forces absorbed to work at the tourist attraction either directly or indirectly. However, in practice, only a few people can be directly involved in Cipendok tourist attraction. The community considers that the existence of tourist attraction does not have a direct impact on additional income. Direct local labor force absorption by the management of Cipendok tourist attraction is only conducted at certain moments, especially during Eid Al Fitr holidays. During holidays, a small number of community will be recruited to become additional parking attendants and other people will trade food at the center of tourist attraction. Therefore, in general, the existence of Curug Cipendok does not have direct economic contribution to the surrounding community.

In addition, there are some locals who can get a job in a hotel established near Curug Cipendok tourist attraction. However, the local labor force absorbed in the hotel is relatively small in number because the hotel owner does not fully use the local labor force, most of the employees are from outside Cipendok area, such as those who have previously worked at Baturaden tourist attraction. The local community is only employed for physical activities, such as construction workers which are only temporary, not for a long term.

From the perspective of bureucracy at the village level, namely Karang tengah village where Curug Cipendok is located, the existence of Curug Cipendok should have a good impact on the surrounding community, especially if the surrounding community can be more involved. Some people consider that there is a negative impact on the community due to the emergence of various entertainments around the site.

In relation to the strategies that need to be implemented as an effort to develop the local economy in Cipendok tourism area, the result of SWOT analysis indicates the operational strategies needed are; 1 ) the synchronization of interests between forest resources manager (PT Perhutani) and local government in encouraging the optimization of the utilization of tourism forest areas to drive the local economy by redesigning the model of Cipendok area development as a major tourist 
destination; 2) Active cooperation between the Regional Government and PT Perhutani and involving the private sector and higher education in determining tourism development strategies and marketing of nature-based tourism products as well as tourism supporting commodities originating from the surrounding community; and 3 ) the region establishing regulation and functions, and focusing on environmental carrying capacity as an appropriate ecotourism impact control and conservation maintenance of ecosystem of environmental assets including local community culture.

\section{CONCLUSION}

Until now, the economic benefits gained by local community on the existence of Curug Cipendok tourist attraction tended to be indirect. The existence of road infrastructure encouraging the increasing mobility of community was an important impact of Cipendok tourist attraction for local community. However, the direct benefits were relatively low, because the absorption of local labor force was limited and the increased service activities around tourist attraction only provided temporary local labor force. Various strategies can be directly applied to improve local economic development process in Cipendok area, such as synchronization of inter-institutional cooperation to encourage tourism and local community involvement and make eco-tourism and environment related regulations, including to attract investment to conduct business in the field of livestock and horticulture around Cipendok area.

\section{REFERENCES}

Agusetyaningrum, V., Mawardi, M.K., Pangestuti, E. (2016). Development strategy for small and medium enterprises (SMEs) to improve the image of Malang City as a culinary tourism destination: Study on Malang City-based culinary cuisine. Journal of Business Administration, 38(2), 105-111.

Ahmad, A.A. and Emmy. (2016). Visitor preference at Cipendok Curug tourism district, Banyumas Regency. EKO-REGIONAL, 8(1).

Demartoto, A. (2009). Community participation in the management of Jumog Waterfall Natural Tourism, Berjo Village, Ngargoyoso District, Karanganyar Regency, Central Java Province. Individual Research in Sociology, Universitas Sebelas Maret.

Government of the Republic of Indonesia. (2009). Law Number 10 of 2009 on Tourism. Government of the Republic of Indonesia.

Primadany, S.R., Mardiyono, and Riyanto. (2013). Analysis of regional tourism development strategies: Study at the Nganjuk Regency culture and tourism office. Journal of Public Administration, 1(4), 135-143.

Purwanti, A. (2015). Arrangement of tourism objects as communication strategies of tourism and culture office in Visit Batam 2010 activities. Journal of Communication, 11(2), 20-40.

Sukmana. (2010). The concept of community empowerment through local potential-based community development: Study in Bunga Sidomulyo Tourism Village, Batu City, East Java. Humanity, 6(1), 59-64.

Suryani, A.I. (2016). Local tourism development strategy. Journal of Spasial, 3(1), 33-42.

TIES (The International Ecotourism Society). (2006). Fact sheet: Global ecotourism (updated edition). Retrieved from www.ecotourism.org

Wijayanti, P., Novianti, T., and Hastuti. (2008). Economic analysis and ecotourism management strategies: Case study of Gunung Salak Endah tourist area in Bogor Regency. Journal of Indonesian Agricultural Science, 13(3).

Yusmiadi, S.D. and Witjaksono, M. (2012). Impact of development of tourism objects on upgrading of local economic development in Blitar Regency. Journal of Economic and Development Studies, 4(1). 